\title{
INVESTOR RATIONALITY: \\ EVIDENCE FROM UK PROPERTY CAPITALIZATION RATES
}

\author{
Patric H. Hendershott \\ Bryan D. MacGregor \\ Working Paper 9894 \\ http://www.nber.org/papers/w9894

\section{NATIONAL BUREAU OF ECONOMIC RESEARCH 1050 Massachusetts Avenue Cambridge, MA 02138}

August 2003

The views expressed herein are those of the authors and not necessarily those of the National Bureau of Economic Research.

(C)2003 by Patric H. Hendershott and Bryan D. MacGregor. All rights reserved. Short sections of text, not to exceed two paragraphs, may be quoted without explicit permission provided that full credit, including (C) notice, is given to the source. 
Investor Rationality: Evidence from UK Property Capitalization Rates

Patric H. Hendershott and Bryan D. MacGregor

NBER Working Paper No. 9894

August 2003

JEL No. G12

\begin{abstract}
Recent analyses have suggested the irrationality of investors in Australian and U.S. office properties. More specifically, investors have failed to raise capitalization rates sufficiently at rental cyclical peaks to account for the obvious mean reversion in real rents and thus have significantly overvalued properties. In this paper we analyze the determination of UK office and retail capitalization rates and provide evidence that these rates reflect rational expectations of mean reversion in future real cash flows. Moreover, these rates are linked to capitalization rates (dividend/price ratio) and expected dividend earnings growth as expected.
\end{abstract}

Patric H. Hendershott

Centre for Property Research

University of Aberdeen Business School

Aberdeen AB24 3UF

Scotland

and NBER

phh3939@uslink.net
Bryan D. MacGregor

Centre for Property Research

University of Aberdeen Business School

Aberdeen AB24 3UF

Scotland

b.d.macgregor@abdn.ac.uk 


\section{Introduction}

Property capitalization rates should be linked to other capital market capitalization rates because all rates should contain the real default-free rate and reflect common risk factors. Each type capitalization rate will, of course, reflect that type's specific risk. Capitalization rates should also be linked to expected real cash flow growth. The higher is expected growth, the more investors will be willing to pay for a current dollar of cash flow and thus the lower the cap rate will be. For property, the cash flow is rent; for stocks the cash flow is dividends. Thus, the movement of real estate capitalization rates relative to stock market capitalization rates should be negatively related to expected real rental growth, but positively related to expected real dividend growth.

How rental growth expectations are formed is crucial to the rationality or efficiency of the property market. ${ }^{1}$ Both Hendershott (1996 and 2000) and Sivitanides et al (2001) argue that investors have not built the "obvious" mean reversion of real rents into their forecasts of real rental growth and thus have overvalued property at rental cyclical peaks (used too low cap rates) and undervalued them at cyclical troughs. Providing evidence on the rationality of the UK property markets is a key component of this paper.

Because data on property capitalization rates are predominately based on appraisals, property cap rates tend to move sluggishly relative to other capitalization rates and proxies for real cash flow growth expectations. Precisely how smooth (auto correlated) cap rates are depends greatly on the nature of the appraisal process and how the cap rate index is constructed (Geltner and Ling, 2000). Thus it is necessary to model the sluggish appraisal process as well as investor behavior.

\footnotetext{
${ }^{1}$ More generally, how real cash flow growth expectations are formed is crucial to the rationality of any market. For a discussion of the U.S. equity market in this context, see Hall (2001).
} 
This paper develops a framework for modelling property cap rates and estimates it using a long-run equilibrium relationship and a short-run adjustment process that reflects both changes to the fundamental explanatory variables and an adjustment to disequilibrium. Section 2 describes the framework that links property cap rates directly to both bond and stock market cap rates. Section 3 reviews the key literature, section 4 presents an error correction model, and section 5 describes data sources and expectation proxies. Results for the UK office and retail markets are reported in sections 6 and 7. Section 8 highlights our major findings and presents additional interpretations and evidence.

\section{Modelling the capitalisation rate}

For long leases with periodic rent reviews, the property cap rate (the ratio of rent to value) is:

$K_{p}=R_{p}-R_{p}\left(\frac{\left(1+G_{p}\right)^{T}-1}{\left(1+R_{p}\right)^{T}-1}\right)$

where $T$ is the period between reviews; $G_{p}$ is the (constant) expected growth rate in rent; and $R_{p}$ is the (constant) property required rate of return. If $T=1$ (annual rent reviews), this reduces to Gordon's growth model:

$K_{p}=R_{p}-g_{p}-\pi$

where we have expressed the growth rate as the sum of expected general inflation $\pi$ and the expected growth in real rent on the property type $g_{p}$.

We specify the required return on property as a weighted average of a mark up on the required return on bonds and a mark down on the required return on stocks $R_{s}$, where $w$ is the 
weight on stocks. Because stocks are more risky than property, this stock-bond premium $\left(\right.$ prem $\left._{s p}\right)$ is subtracted:

$$
R_{p}=w\left(R_{s}-\operatorname{prem}_{s p}\right)+(1-w)\left(R R_{b}+\pi+\operatorname{prem}_{p b}\right)
$$

where $R R_{b}$ is the real default-free rate.

Assuming continuous growth in dividends and a constant required equity return, the required return can be expressed as the sum of the cap rate for corporate stocks (the dividend/price ratio) and the expected growth rate in dividends. Again partitioning the growth rate into general inflation and real growth,

$R_{s}=K_{s}+g_{s}+\pi$

Substituting (4) into (3), the result into equation (2), and cancelling the inflation terms, we obtain:

$K_{p}=w K_{s}+w g_{s}-$ pprem $_{s p}+(1-w) R R_{b}+(1-w)$ prem $_{p b}-g_{p}$

Of course if w is zero, property is priced solely off of bonds, and if w is unity, property is priced only off of stocks or shares. Unfortunately, only one of the six variables in this equation, the dividend/price ratio, is observed.

Given that lease rates do not adjust annually, that real cash-flow growth is not expected to be constant forever into the future, and that expected future one-period returns are not necessarily constant, this relationship is not expected to hold exactly. 


\section{Literature}

The early literature on modelling real estate cap rates emphasized the link to the bond market and estimated simple lag structures. For the UK, Hetherington (1988) modeled appraisal-based cap rates from Hillier Parker and Key et al. (1994) modeled the UK allproperty appraisal-based cap rate from the Investment Property Databank. Some early U.S. work recognized the links to the stock market as well. Both Evans (1990) and Ambrose and Nourse (1993) estimated the link between the S\&P 500 and the ACLI market cap rates. Jud and Winkler (1995) and Viezer (1999) modeled market cap rates for property types from the National Real Estate Index, the former emphasizing links to both the bond and stock markets and the latter to the bond market only.

Sophisticated lag structures have been estimated only recently. Sivitanidou and Sivitanides (1999) use the National Real Estate Index (twice yearly from the end of 1985 to the end of 1995 for each of 17 MSAs) for office properties. They identify the discount rate and income growth expectations as the key components affecting cap rates. Both are affected by variables that could be time invariant or time variant. They consider two sets of variables: local office market effects; and time variant effects in the local office markets and national capital market. A process of adjustment to equilibrium is specified.

The equilibrium cap rate $C^{e}$ is given by

$C_{j t}^{e}=a_{j} L_{j}+b_{j} F(t)$

where $L_{j}$ is a vector of metropolitan dummies (so that the estimated values of $a_{j}$ represent fixed local effects), $F(t)$ represents time variant effects, $j$ denotes metropolitan areas and $t$ is a time index. The actual cap rate $\mathrm{C}$ is the equilibrium value plus an autoregressive error, thus 
$C_{j t}=a_{j} L_{j}+b_{j} F(t)+\rho_{j} \varepsilon_{j t-1}+v_{j t}$

where $\rho$ denotes the serial correlation coefficient and $v_{t}$ is an independent random error term.

In the first set of estimations, cap rates are modelled in panel with spatially varying intercepts, a deterministic time trend $\left(F(t)=t /\left(1+t^{2}\right)\right)$ with spatially variable coefficients and a spatially varying autoregressive error. It is estimated using the Seemingly Unrelated Regressions (SUR) procedure to account for cross-sectionally correlated metropolitan-specific errors. The results show significant inter-market differences in the local-fixed component (showing differential risk perceptions and income growth expectations). There is also evidence of differences in persistence in the errors ( $\rho$ different) and the $b_{j}$ 's are unequal. In the second set of estimations, the model is

$C_{j t}=a_{j}+F\left(L_{j}, M_{j t}, X_{t}\right)+\rho_{j} \varepsilon_{j t-1}+v_{j t}$

where $L_{j}$ still denotes time-invariant traits of local office markets; $M_{j t}$ represents time-variant features of the local office markets; $X_{t}$ represent time-variant features of the national capital market. Three versions are estimated: fixed effects ( $a_{j}$ and $\rho$ are constant for all markets); $\rho$ only constant for all markets; both $a_{j}$ and $\rho$ variable.

While this is the most detailed attempt to model real property cap rates, it is not without problems. The adjustment process is modelled through an AR error. However, serial correlation in residuals does not necessarily imply serial correlation in the disturbances: it may be the result of a more fundamental problem of an omitted, but relevant, autocorrelated 
independent variable (Harvey, 1990, Darnell, 1994). ${ }^{2}$ The authors acknowledge this possibility. Moreover, in the first model, the deterministic time trend, based on a quadratic decline, is surely a time specific phenomenon of a period when cap rates were falling. This declining trend may point to possible problems with the order of integration of the variables in the estimation. Further, it is possible that other methods of composing the series would be more appropriate and might not result in an AR error. In the second model, it is uncertain whether the local fixed effects can really be regarded as fixed over a 10-year period. Finally, if the model were expressed in differences, the coefficients on the explanatory variables would be constrained to be equal to those in the levels model. This implies a constrained adjustment process.

Sivitanides et al. (2001) examine NCREIF cap rate data. For office and industrial properties, data are from 14 metropolitan markets for the 1984-2000 period; for retail and multifamily properties data are for only 9 markets and begin as late as 1990 . The primary economic determinants are two real rent series analogous to our series, the ratio of real rent to its average over the 1980-99 period and the annual growth rate in real rent. Unlike our results, though, the real rent level variable has a negative coefficient, which is inconsistent with an expectation of mean reversion in real rents. Other variables include the lagged log of the capitalization rate, the Treasury bill rate, the CPI inflation rate (national, rather than by MSA) and city fixed effects.

From the above review, a number of common issues emerge. First, the models of cap rates have been estimated in levels rather than differences. Second, and related, attention does not seem to have been given to orders of integration of the variables or of co-integration

\footnotetext{
${ }^{2}$ For a dynamic regression, serial correlation may also reflect inappropriate specification of the system dynamics. Harvey $(1990,288)$ suggests that if 
among variables. Finally, the short-run dynamic adjustment process is unsatisfactorily modelled or not modelled at all.

\section{Estimation: An error correction model}

Error correction models (ECMs) are used widely in econometrics. The central notion is of a steady-state relationship between variables that are evolving over time. This long-run relationship is a time-varying equilibrium to which the system tends. An ECM comprises both the long-run relationship and the short-run transitory effects and describes how the longrun solution is achieved through negative feedback and error correction (Harvey, 1990; Darnell, 1994).

The long-run relationship is specified in levels, and the short-run adjustment in first differences. The long-run or equilibrium relationship is:

$K_{t}^{*}=\beta_{0}+\sum_{i=1}^{n} \beta_{i} X_{i t}$

where $K_{t}^{*}$ is the cap rate and $X_{i t}$ are explanatory variables at time $t$. Replacing $K^{*}$ with $K$ and estimating, the residual of this equation is:

$u_{t}=K_{t}-\hat{\beta}_{0}-\sum_{i=1}^{n} \hat{\beta}_{i} X_{i t}$

the difference between the actual and estimated equilibrium values of the cap rate. If this term is stationary, its lagged value can be used in the short-run model as an Error Correction term. 
Short-term changes in the variable of interest are driven by changes in the explanatory variables in the long run relationship and by adjustments to previous disequilibrium in the long-run relationship.

$k_{t}=\alpha_{0}+\sum_{i=1}^{n} \alpha_{i} x_{i t}-\mu_{t-1}$

where $k_{t}$ denotes the first difference of $K_{t}$ and $x_{i t}$ the first difference of $X_{i t}$. Thus, the cap rate adjusts to short-run changes in the causal variables and also to the lagged disequilibrium. The degree of adjustment is indicated by the coefficient, $\gamma: \gamma=1$ means full adjustment, $0<\gamma<1$ means partial adjustment and $\gamma=0$ means no adjustment. We would expect that $\alpha_{0}=0$.

We would also not be surprised if the $\alpha_{\mathrm{i}}$ were proportional to the $\beta_{i}$, in which case $a k^{*}$ could replace the summation in equation (11). A more general specification can include multiple lags of the explanatory variables and of the dependent variables.

There are two rationales for applying an ECM to capitalization rates. First, cap rates effectively determine prices, and prices are often viewed as periodically deviating from equilibrium values temporarily owing to market enthusiasm and a variety of transaction costs that limit trading against optimists. The lagged change in price could capture market momentum, and the difference between the actual and equilibrium prices could reflect the underlying forces operating to return the market to equilibrium. ${ }^{3}$ Second, the optimal appraisal process weights current and past transactions prices of similar properties (Quan and Quigley, 1991). Given our use of appraisal data, the ECM could be capturing this process.

The only study to use an ECM for cap rates is that of McGough and Tsolacos (2001) who estimate a vector autoregressive model with error correction mechanisms (VECM) to

\footnotetext{
${ }^{3}$ In house price research, the lagged price change has been described as a "bubble" builder" and the actualequilibrium price gap as a "bubble burster" (Abraham and Hendershott, 1996).
} 
explain IPD appraisal-based cap rates. ${ }^{4}$ The significant variables in the VECM are: the first three lags of the change in the cap rate; the third lag of the change in the yield on 10 year Government bonds; the second lag of the change in the dividend yield from the FT Actuaries All Share Index. The ECM is not significant. The insignificance of the error correction term in the VECM is disappointing but may result from the restricted range of explanatory variables, the inclusion of numerous lagged values of the explanatory variables in the shortrun model and the short period over which adjustment is allowed (three months).

\section{Data sources and description}

\section{Capitalization rates}

Ideally, capitalization rates would be based on transactions of constant-quality (including location) properties with identical lease terms. Of course, such data don't exist. Our rent and capitalization rates represent appraisers' quarterly estimates for notional newlylet new properties with standard characteristics and the standard UK lease in 731 particular prime locations. ${ }^{5}$ That is, these data are ideal except that they are not based on actual transactions. The series are publically available from Hillier Parker from the first quarter of 1972. The retail price index is used to deflate nominal rent and dividend series. All financial and economic data are from DataStream.

Figure 1 plots quarterly values of the UK office and retail cap rates, the share dividend/price ratio and the 20-year government bond new issue rate. The share and bond yields move together (correlation of 0.84 for the period 1973.3 to 2001.4), as do the office and retail cap rates $(0.82)$. But property does not correlate with either shares or bonds. The

\footnotetext{
${ }^{4}$ Hendershott, MacGregor and White (2002) use this framework to explain panels of UK regional real rents.

${ }^{5}$ There are 162 points in the office index, of which 83 are in the greater London area, reflecting the concentration of the office investment market. There are 459 points in the retail index, of which only 78 are in London.
} 
correlations of office and retail cap rates with bond rates are -0.25 and -0.15 , respectively; with shares the correlations are -0.03 and -0.04 .

One reason for the lack of correlation with cap rates in the stock and bond markets is the far higher serial correlation in property cap rates. The serial correlation of first differences of the property cap rates is 0.67 for retail and 0.57 for offices, while that of shares is 0.08 and bonds is 0.18 . The slow adjustment to changes in causal variables makes property cap rates difficult to model. This problem is compounded by the importance of expectations in the determination of cap rates and the need to identify suitable proxy variables for these expectations. Many of these variables, too, exhibit substantially greater volatility than property cap rates.

\section{Proxies for expected real cash flow growth}

Dividends and real rents for both offices and retail exhibit high first order serial correlation (all 0.98 in our data). However, the serial correlation of percentage changes is far greater for rents than dividends ( 0.87 and 0.77 versus 0.20$)$. The three income series exhibit long horizon mean reversion or trend reversion. ${ }^{6}$ Figure 2 plots real office and retail rents per unit space and real dividends, all scaled to unity in 1988.1. Real office rents have no trend, real retail rents have a modest trend (1.35 per cent per year), and real dividends grow at about 5.3 per cent per year. The lower trends in real rent relative to real dividends reflect both the ease of production of additional space and the retention of corporate earnings for investment.

Expected future growth in real cash flows should reflect both the observed serial correlation and mean (or trend) reversion. We capture mean reversion by using the fourquarter average (current and previous three quarters) of the deviation of the log of real rent or

\footnotetext{
${ }^{6}$ For earlier evidence on the properties of real rents in a number of countries, see Wheaton and Torto (1994), Hendershott (1996) and Hendershott, Lizieri and Matysiak (1999); on real US dividends, see Shiller (1981) and Campbell and Shiller (1989).
} 
dividends from a linear trend. A high/low level will be expected to revert to the trend, raising/lowering the cap rate. ${ }^{7}$ We capture serial correlation by using one-year moving averages of changes in real cash flows; high recent growth will be extrapolated forward, lowering the cap rate.

On average, one would anticipate that actual future growth in real cash flows would be positively correlated with expected future cash flow growth, as least over limited time periods. Thus we would expect future real cash flows to be correlated with our deviation from trend (negatively) and recent growth (positive). This is, indeed, the case.

The three sections of Table 1 report these correlations for our three real cash-flow variables - office rent, retail rent, and dividends. The top of each section shows the correlations of the mean reversion and recent growth proxies. For rents, the correlations are effectively zero. For dividends there is a slight negative correlation. The rest of the sections show the correlations of the mean reversion and recent growth proxies with future actual real rental growth at intervals of one to five years. As can be seen, the negative correlation with the mean reversion proxy becomes stronger the more years of growth are considered, rising from roughly (minus) 0.5 to 0.6 at one year to 0.8 or 0.9 at five years. The positive correlation with the extrapolation proxy, in contrast, declines as more years are considered, dropping from 0.45 to 0.65 at year one to less than 0.1 at year four.

\section{Proxies for risk premia}

For the stock-property risk premium, the volatilities in recent property and stockmarket total returns are candidates for proxies. The volatility in recent property returns is also

\footnotetext{
${ }^{7}$ Hendershott (2000, pp 74-76) reports calculations suggesting an enormous rational decline in the Sydney office market cap during the 1989-93 real rent collapse (real effective rents fell by two-thirds to a level far below equilibrium).
} 
relevant to the property-bond premium, as is the volatility of recent inflation because property is a superior inflation hedge than bonds. In practice, only the volatility of total real returns on the stock market was significant in early models and, as its impact was marginal, it was not included in the final models reported below. ${ }^{8}$

It is well known that UK institutions have been moving out of property for the last twenty years. In 1979, 18 per cent of life and pension fund portfolios was invested in property; by 1999, only 4 percent (the data are from the Investment Property Databank). This is a consequence of both portfolio revaluation and differential flows of new capital.

(Property's share of net institutional new investment fell from a peak of around 25\% in 1974 to $0 \%$ in 1996 and then rose to $10 \%$ in 2000 , DTZ Research, 2001.) The decline in the property weight probably reflects an increase in the risk premium demanded on property by institutional investors, in which case property values would have fallen and cap rates would be higher. On the other hand, the portfolio decline could reflect a decrease in the property risk premium demanded by other investors, in which case property prices would have risen and cap rates would be lower. That is, the reduced institutional share could reflect others bidding for property rather than institutions dumping property. In the former case, we would expect higher property prices (lower cap rates); in the latter, lower prices (higher cap rates). Of course, if each of these changes were occurring at different times, the portfolio shift variable will not work in the estimation. ${ }^{9}$

A time trend is included to pick up trends in liquidity premia, in depreciation rates, or in other missing factors.

\footnotetext{
${ }^{8}$ Other possible proxies for the risk premium on property were tested without success. They included recent volatility of national GDP and output and employment related to the office and retail markets and of inflation. Inflation volatility worked in some models but these regressions had other unsatisfactory features.

${ }^{9}$ We also tried a variety of other 'weight of money' variables, including net institutional investment in property, property company debt, property company lending as a percentage of total bank lending, property company share issues and new construction. Some worked modestly but none nearly as well as portfolio share.
} 
Table 2 shows that all of the cap rates, the property weight and real dividends are integrated of order one (stationary in the first differences). The two real rent variables are order zero (stationary), according to the Augmented Dickey-Fuller test, and order one, according to Phillips-Perron test. If the order is one, we cannot include rents in the tests of co-integration. In these tests, there are no problems with establishing at least one cointegrating vector for the office market and, moreover, the residuals are stationary. The results for the retail model are a little less conclusive - using the Akaike criterion for model selection produces the desired result but the Schwarz criterion does not. However, the residuals are again stationary (see Appendix 1 for the full results).

The relatively high volatility of many of the likely explanatory variables in comparison to cap rates pointed to the need to construct moving averages of many of these. The use of fourquarter moving averages restricts our estimations to start in 1973. Quality property portfolio weight data are available only beginning in 1977 (earlier data are based on book rather than market values) and the series currently ends in 2001. Thus we report estimations for 19782001. However, because we really have only 2.5 cycles of data and the 1973-76 period amounts to nearly a full cycle, we illustrate the robustness of our principal findings on the importance of expectations of real rental growth using data from the full period from 1973.

\section{Office Market Results}

Table 3 contains estimates of the long-run relationship based on equation (5) estimated over the period from the fourth quarter of 1977 (77.4) to the end of 2001 (01.4). We have effectively assumed the real bond rate to be constant (above and beyond any relationship to the variables included to reflect variations in the expected growth in real cash flows or the property risk premium). Indexed linked bonds did not become available until 1986, and we 
despair of modelling long-term expected inflation. ${ }^{10}$ We include the stock market capitalization rate (dividend/price ratio), the real cash flow deviation from trend and rate of change variables for both property (office rent) and stocks (dividends), and the property portfolio weight. The first equation includes a time trend and the second does not.

All variables are highly significant (all rent coefficients have t-ratios of above 8 ) and are appropriately signed. The adjusted $\mathrm{R}^{2}$ is 90 percent with the trend and 85 percent without. The log deviation of real office rent from its trend (mean) has a positive sign. If real rent is above trend, it is expected to fall and the implied lower rental growth is reflected in a higher cap rate. If real rent were 50 percent above trend, as it was in 1974 and 1990, the cap rate would be one and a half percentage points higher, while if real rent were 20 percent below normal, as in 1977-84 and 1994-95, the cap rate would be a half percentage point lower. The four-period moving average of real rental growth has a negative sign. Thus, if current rental growth were high, expectations of further growth would necessitate a lower cap rate. The rapid five percent quarterly real rental growth during mid1987-mid1988 translates into a percentage point lower cap rate, while the sharp declines during 1975-76 and 1991-92 imply the reverse.

The coefficient on the dividend-price ratio is only 0.18 with a t-ratio of two, suggesting that property is priced more off the bond market than off the stock market. Nonetheless the significance of the dividend-price ratio and both the real dividend growth rate and real dividend deviations from trend (with the expected signs) is strong evidence that office property is priced off the stock market.

\footnotetext{
${ }^{10}$ Sivitanides et. al. (2001) use the previous year's percentage change in the CPI as the proxy for ten-year expected inflation and obtain coefficients on it (and the nominal Treasury bill rate) that are far below the expected unity value. We have constructed a real rate series assuming it was constant prior to 1986 . When included in our trend model, the variable had a coefficient of 0.13 , far lower than the expected unity value, with a t-ratio of 1.9. The coefficient was lower in the non-trend model, and when the models were estimated on the 1986-2001 data, the coefficient turned negative.
} 
If mean reversion and rental momentum were the same in the property and stock markets, we would expect the coefficients on the variables based on dividends to be roughly $w$ those based on rents, where the estimated $w$ was 0.18 . Of course $w$ is estimated with error; lowering and increasing it by a standard error gives a range of 0.09 to 0.27 . In fact the estimated ratio of dividend to rent coefficients is 0.11 for the growth variables and 0.68 for the mean reversion variables. This exercise suggests that while investor's extrapolation of the growth in real dividends and rents is similar, mean reversion in the office market is weaker than in the stock market. This result is not surprising given that both Hendershott (2000) and Sivitanides, etal. (2001) report zero or even negative expected reversion of real rents by investors. Overall, though, the importance of the cash-flow variables with the expected impacts is an especially appealing result of the estimations.

The property weight and trend variables are highly significant with economically large coefficients, but their impacts are largely offsetting. As noted above, the property weight fell from 18 percent to four per cent during the $1979-1999$ period. With a coefficient of -0.37 , this translates into a huge 5.2 percentage-point rise in the cap rate. On the other hand, a negative time trend of 0.036 per quarter for 80 quarters cumulates to a 2.9 percentage point decline in the cap rate, giving a net effect of the two variables of a 2.3 percentage point rise in the cap rate over the twenty years.

When the time trend is excluded (the second equation in Table 3), the coefficient on the property weight variable is halved to compensate. The 14 percentage-point decline in the weight now implies a 2.4 percentage point $(0.17 * 14)$ rise in the cap rate. All the cash-flow variables work as before, although the level (mean reversion) coefficients decline by 10 to 20 percent in absolute magnitude and the flow coefficients rise, especially the low dividend coefficient. 
Figure 3 plots the actual and fitted values of the cap rate (the third series in the figure is discussed shortly). As can be seen, the actual series oscillates throughout the 1980s before jumping by two percentage points in 1990 and early 1991. Roughly two years later, in late 1993 and early 1994, the two-point increase was reversed. Not surprisingly, the estimated equation captures the broad movement in the cap rate, although significant, reversing, errors occur periodically, suggesting the need for an error correction framework.

We next estimate the short-run adjustment model, initially including changes in all the long-run model variables, the lagged dependent variable to expand the dynamic adjustment process, and the ECM variable. All the change variables enter with the expected signs and most are 25 to 42 percent of their coefficient in the long run equation (see Table 4). The two exceptions are the dividend-price ratio, whose short-run coefficient is 59 percent of the longrun coefficient, and the deviation of dividends from trend, whose short-run coefficient is 121 percent. Both of these coefficients have t-ratios around 2.3. The other t-ratios range from 1.4 to 1.9. The lagged dependent and ECM variables have t-ratios of 3.5 and 5.0 and suggest autocorrelation of 0.3 and error correction of 0.25 . The adjusted $\mathrm{R}^{2}$ is $45 \%$. The actual and fitted values are shown in Figure 4. The model picks up the broad movements of the cap rate change well, although it does not fully capture the 1.12 percentage point plunge in 1994.2.

To determine how well our preferred equations from the two-part estimation - the long and short run equations - really explain the cap rate, we have simulated the estimated cap rate dynamically. In this simulation we compute the change in the cap rate each quarter going forward using the difference equation coefficients, but the lagged cap rate in the simulation is always that obtained from the previous simulation, rather than the actual lagged cap rate. In this way, errors in the estimation are allowed to accumulate over time. This is the third series in Figure 3. 
As can be seen, when lag gaps between the actual and long run capitalization rates exist, the dynamically simulated cap rate tends to narrow the difference. The gap between the estimated and actual cap rate is more than 50 basis points during 87.1-88.2 and 93.1-94.1 and less than -50 basis points in $89.2-90.1$. In the first two periods the average differences are 75 and 61 basis points. The dynamically predicted cap rate, in contrast, differs from the actual cap rate by only 64 and 29 basis points. In the third case, the average estimated long run gap is -55 basis points and the dynamically fitted gap is again smaller, -29 basis points. On average, the gaps are reduced by 34 percent.

\section{Retail Market Results}

Table 5 contains the estimated long-run relationship for retail cap rates. All the coefficients are correctly signed, although those on the dividend price ratio, the dividend growth rate and the trend variable are less than their standard errors. Because the coefficient on the time trend is trivial, excluding it has only modest impacts on the other coefficients. Thus no equation is reported without the trend. The -0.20 coefficient on the portfolio weight variable combined with the 14 point drop gives a 2.8 percentage point rise in the cap rate between 1980 and 2000. The adjusted $\mathrm{R}^{2}$ is 85 percent.

The rent and dividend level coefficients are about 60 percent larger than in the office market equation, suggesting stronger mean reversion generally. If real rent were 30 percent

above trend, as it was in $1989-90$, the cap rate would be 1.5 percentage points higher, while if real rent were 20 percent below normal, as in 1983-84, the cap rate would be a percentage point lower. On the other hand, if current rental growth were high, expectations of further growth would necessitate a lower cap rate. The rapid five percent quarterly real rental growth during 1987-88 translates into a two-thirds percentage point lower cap rate. 
The small coefficient on the dividend growth variable is consistent with the small coefficient on the dividend-price ratio. What is surprising is how large the coefficient is on dividend reversion relative to rent reversion. Again, this result is consistent with less mean reversion in property markets relative to the stock market.

Figure 5 plots the actual, fitted and the dynamically simulated. Our ability to explain the long-run movement in the retail cap rate is less than our ability to explain the office cap rate. The cap rate is underpredicted at the beginning of the period and at the end of the period. Also, the sharp movement during 1989-mid94 is only partially explained.

Table 6 contains the short-run adjustment equation. All coefficients on changes in the variables appearing in the long-run equation are correctly signed, but only that on the change in the dividend-price ratio is statistically significant. The second equation in the table includes only the lagged dependent variable, the error correction and the dividend-price ratio. The error correction is smaller than that for offices, while the auto correlation is close to double that in the office market. The $\mathrm{R}^{2}$ is 46 percent. Figure 6 gives the actual and fitted values and residuals. The fitted follows the path of actual cap rate changes reasonably well throughout the period but, as with the office model, the spike in 1994 is largely missed.

As noted above, the actual retail cap rate does not track the long-run fitted value as closely as was the case for the office cap rate. Whereas we identified three periods of substantial continuous gaps between the actual and long-run fitted cap rates for offices, here we identify five. The actual exceeded the equilibrium by 70 basis points during 78.1-79.2 and 67 basis points during 2001. The dynamic adjustment halved the first gap, but actually increased the second by 6 basis points. On the other hand, the equilibrium rate exceeded the actual by 46 basis points during $85.2-86.1,68$ basis points in 1989, and 58 basis points during 94.2-94.4. On average, the dynamic equation reduced the gaps by only 14 percent (to 46 from 54 basis 
points), far less than the 34 percent reduction of the office market gap. That is, neither the long run relationship nor the short-run adjustment is as good for retail as for offices.

\section{Discussion and further work}

From these estimations for office and retail cap rates, it is clear that a model can be estimated that is generally consistent with the cap rate analysis in section 2 . It is also clear that the ECM is a useful formulation for the analysis. Some caution is, however, required for this final conclusion. While the stock and two property cap rates are integrated of order one during the period of analysis, there is no reason to suppose that these would be anything other than stationary over a much longer period. If this were the case, a levels estimation would be appropriate.

Especially noteworthy is the importance of proxies for expected growth in real cash flows (reflecting both extrapolative growth expectations and mean reversion). We have reproduced the mean reversion and extrapolation regression coefficients for both models both with and without the trend variable in the first two columns of Table 7, with office at the top of the table and retail underneath. In the third and fourth columns we have done the same based on estimation over the longer mid1973-2001 period, which adds nearly another full rent cycle. In this estimation the property portfolio weight variable prior to 1977.1 is set equal to the 1977.1 value due to its unavailability prior to then. For offices, only one of the rent coefficients changes by as much as 10 percent. For retail, the mean reversion coefficients decline by 15 and 60 percent, while the extrapolation coefficients rise (absolutely) by a quarter and two-thirds.

The standard errors for the four office mean reversion coefficients are 0.3 and the coefficients themselves range from 2.2 to 3.2 , averaging 283. The standard errors for the extrapolation coefficients are in the 1.6 to 2.3 range and the coefficients range from -15.9 to 21.3 and average -18.5 . That is, the t-ratios always exceed 7 and average 10. Moreover the 
impacts are large. When real office rents are 50 percent above the mean (1974 and 1990), the cap rate would be one to one and a half percentage points higher. And when real rents are 20 percent below the mean (1977-84 and 1994-95), the cap rate would be a third to two-thirds percentage points lower. A year of rapid growth in real office rents (five percent quarterly) also has a major impact, lowering the cap rate by a percentage point or more because investors are willing to pay more for a dollar of rent that is expected to grow rapidly. The rent variables explain much of the extraordinary hump in cap rates during the 1990-92 period.

The standard errors for the four retail mean reversion coefficients are 0.6 and the coefficients themselves range from 2.0 to 5.2 and average 4.2. The standard errors for the extrapolation coefficients are in the 3.5 to 4.1 range and the coefficients range from -13.3 to 23.6 and average -16.9 . All the t-ratios exceed 3, and the mean reversion coefficients average nearly 7.

Our results are strikingly different from those of Sivitanides et al (2001), who report a negative sign on the ratio of real rent to its mean value, suggesting that investors irrationally extrapolate far above normal real rents to rise even further. Not only do our real rent proxies work as expected, that is, are consistent with rational expectations of mean reversion, but the real dividend proxies work correctly as well. That is, real dividends being above trend lead to expectations that real dividends will fall and thus that property is relatively more attractive. As a result, the property cap rate falls. This is true for both office and retail properties.

Of course, cap rates can be converted to values by dividing them into market rents. We have divided actual rents first by actual cap rates and then by the dynamically simulated office market cap rate described above and graph the two series in Figures 7 (offices) and 8 (retail). As can be seen, the office model tracks value reasonably closely. The model explains all but the last sixth of the 1985-89 rise in office value and all of the entire subsequent decline, and otherwise tracks value closely. The retail equation does not perform as well. 


\section{References}

Abraham, J and Hendershott, P H (1996) Bubbles in Metropolitan Housing Markets, Journal of Housing Research, 7, 191-207.

Ambrose, B and Nourse H O (1993) Factors Influencing Capitalization Rates, Journal of Real Estate Research, 8, 221-237.

Campbell, J Y and Shiller, R J (1989) The Dividend-Price Ratio and Expectations of Future Dividends and Discount Factors, The Review of Financial Studies, 1, 195-228.

Darnell, A C (1994) A Dictionary of Econometrics, Edward Elgar, Cheltenham.

Evans (1990) A Transfer Function Analysis of Real Estate Capitalization Rates, Journal of Real Estate Research, 5, 371-379.

Geltner, D and Ling D C (2001) Ideal Research and Benchmark Indexes in Private Real Estate: Some Conclusions from the RERI/PREA Technical Report, Real Estate Finance, 17, $17-28$.

Hall, R E (2001) Struggling to Understand the Stock Market, American Economic Association Papers and Proceedings, 91, 1-11.

Harvey, A C (1990) The Econometric Analysis of Time Series, Philip Allan, London.

Hendershott, P H (1996) Rental Adjustment and Valuation in Overbuilt Markets: Evidence from the Sydney Office Market, Journal of Urban Economics, 39, 51-67.

Hendershott, P H (2000) Property Asset Bubbles: Evidence from the Sydney Office Market, Journal of Real Estate Finance and Economics, 20, 67-81.

Hendershott, P H, Lizieri, C M, and Matysiak, G A (1999) The Workings of the London Office Market, Real Estate Economics, 27, 365-387.

Hendershott, P H, MacGregor, B D and White, M (2002) A Panel Approach to Modelling Regional Rents in the UK Commercial Property Market, The Journal Real Estate Finance and Economics, 24, 59-87.

Hetherington, J (1988) Forecasting of Rents, in A MacLeary and N. Nanthakumaran (eds.) Property Investment Theory, London: D \& F.N. Spon., 97-107.

Jud, D and Winkler, D (1995) The Capitalization Rate of Commercial Properties and Market Returns, Journal of Real Estate Research, 10, 509-518.

Key, T, MacGregor, B D, Nanthakumaran, N and Zarkesh, F (1994) Understanding the Property Cycle, RICS, London.

McGough, T and Tsolacos, S (2001) Do Yields Reflect Property Market Fundamentals? Real Estate and Finance Investment Research Paper, 2001.01, City University Business School, London. 
Quan, D. and J. Quigley (1991) Price Formation and the Appraisal Function in Real Estate Markets, Journal of Real Estate Finance and Economics, 4, 127-146.

Shiller, R (1981) Do Stock Prices Move Too Much to Be Justified by Subsequent Changes in Dividends? American Economic Review, 71, 421-36.

Sivitanidou, R and Sitivanides, P (1999) Office Capitalization Rates: Real Estate and Capital Market Influences, Journal of Real Estate Finance and Economics, 18, 297-322.

Sivitanides, P, Southard, J, Torto, R and Wheaton, W (2001) The Determinants of AppraisalBased Capitalization Rates, Real Estate Finance, 18, 27-37.

Viezer, T W (1999) Econometric Integration of Real Estate's Space and Capital Markets, Journal of Real Estate Research, 18, 503-19.

Wheaton, W and Torto, R (1994) Office Rent Indexes and Their Behaviour over Time, Journal of Urban Economics, 35, 121-39. 
Table 1: Correlations between expected rental growth proxies and actual rental growth (1973.3 to 1996.4)

(a) Offices

Last 4 q rental

Mean reversion growth

\begin{tabular}{lll}
\hline Mean reversion & 1.00 & 0.02 \\
Last 4 q rental growth & 0.02 & 1.00 \\
\hline 4 q forward rental growth & -0.57 & 0.65 \\
8 q forward rental growth & -0.73 & 0.42 \\
12 q forward rental growth & -0.82 & 0.22 \\
16 q forward rental growth & -0.87 & 0.06 \\
20 q forward rental growth & -0.89 & -0.04 \\
\hline
\end{tabular}

(b) Retail

Last $4 \mathrm{q}$ rental

Mean reversion growth

\begin{tabular}{lll}
\hline Mean reversion & 1.00 & 0.05 \\
Last 4 q rental growth & 0.05 & 1.00 \\
\hline 4 q forward rental growth & -0.53 & 0.54 \\
8 q forward rental growth & -0.69 & 0.30 \\
12 q forward rental growth & -0.78 & 0.12 \\
16 q forward rental growth & -0.83 & -0.02 \\
20 q forward rental growth & -0.85 & -0.09 \\
\hline
\end{tabular}

(c) Dividends

Last $4 \mathrm{q}$

Dividends

Trend reversion

Trend reversion dividend growth

Last $4 \mathrm{q}$ dividend growth

$4 \mathrm{q}$ forward dividend growth

$8 \mathrm{q}$ forward dividend growth

$12 \mathrm{q}$ forward dividend growth

$16 \mathrm{q}$ forward dividend growth

$20 \mathrm{q}$ forward dividend growth
1.00

$-0.19$

$-0.59$

$-0.74$

$-0.79$

$-0.81$

$-0.81$
$-0.19$

1.00

0.45

0.37

0.22

0.08

0.06 
Table 2: Descriptive statistics

\begin{tabular}{lccccc}
\hline & Mean & Maximum & Minimum & Std. Dev. & Order of integration \\
\hline Office cap rate & 6.78 & 9.02 & 5.15 & 1.04 & $\mathrm{I}(1)$ \\
Retail cap rate & 5.51 & 7.27 & 4.25 & 0.98 & $\mathrm{I}(1)$ \\
Stocks cap rate & 4.36 & 6.66 & 2.29 & 1.07 & $\mathrm{I}(1)$ \\
Office - stocks cap rate & 2.42 & 4.84 & -1.49 & 1.74 & $\mathrm{I}(1)$ \\
Retail - stocks cap rate & 1.15 & 4.39 & -2.33 & 1.74 & $\mathrm{I}(1)$ \\
\hline Real office rental level 4 & -0.04 & 0.49 & -0.27 & 0.22 & $\mathrm{I}(0)$ - ADF; I $(1)-\mathrm{PP}$ \\
Real retail rental level 4 & -0.02 & 0.31 & -0.20 & 0.14 & $\mathrm{I}(0)$ - ADF; I $(1)-$ PP \\
Real dividend level 4 & -0.02 & 0.17 & -0.22 & 0.10 & $\mathrm{I}(1)$ \\
\hline Real office rental growth 4 & 0.00 & 0.07 & -0.07 & 0.03 & $\mathrm{I}(0)$ \\
Real retail rental growth 4 & 0.01 & 0.07 & -0.02 & 0.02 & $\mathrm{I}(0)$ \\
Real dividend growth 4 & 0.06 & 0.25 & -0.10 & 0.07 & $\mathrm{I}(0)$ \\
\hline Property weight 4 & 10.57 & 19.12 & 4.40 & 4.82 & $\mathrm{I}(1)$ \\
\hline
\end{tabular}

\section{Notes:}

(1) There are 97 observations from $1977 \mathrm{q} 4$ to $2001 \mathrm{q} 4$ inclusive.

(2) Variables with a '4' are four quarter moving averages.

(3) The rental and dividend level variables are deviations from a fitted exponential trend, although the trend is insignificant for the two property variables. The trend is calculated for the full period for which there is rental data - $1972 \mathrm{q} 3$ to $2001 \mathrm{q} 4$.

(4) ADF - Augmented Dickey-Fuller; PP - Phillips-Perron. 
Table 3: Long run model of the office market

\section{(a) With trend}

Dependent Variable: Office cap rate

Sample: 1977:4 to 2001:4

Included observations: 97

\begin{tabular}{ccccc}
\hline Variable & Coefficient & Std. Error & t-statistic & Prob. \\
\hline Constant & 12.65 & 0.80 & 15.83 & 0.0000 \\
Stock cap rate & 0.180 & 0.090 & 2.00 & 0.049 \\
Rental deviation 4 & 3.19 & 0.27 & 11.88 & 0.0000 \\
Real rental growth 4 & -16.61 & 1.98 & -8.38 & 0.0000 \\
Real dividend deviation 4 & -2.17 & 0.67 & -3.24 & 0.0017 \\
Real dividend growth 4 & 1.92 & 0.78 & 2.48 & 0.015 \\
Property weight 4 & -0.368 & 0.036 & -10.11 & 0.0000 \\
$\quad$ Linear trend & -0.0363 & 0.0055 & -6.59 & 0.0000 \\
\hline R-squared & 0.904 & F-statistic & 119.69 \\
Adjusted R-squared & 0.896 & Prob. (F-statistic) & & 0.0000 \\
S.E. of regression & 0.33 & Durbin-Watson & & 0.33 \\
\hline
\end{tabular}

(b) Without trend

Dependent Variable: Office cap rate

Sample: 1977:4 to $2001: 4$

Included observations: 97

\begin{tabular}{ccccc}
\hline Variable & Coefficient & Std. Error & t-statistic & Prob. \\
\hline Constant & 7.61 & 0.28 & 26.95 & 0.0000 \\
Stock cap rate & 0.20 & 0.11 & 1.81 & 0.074 \\
Rental deviation 4 & 2.72 & 0.31 & 8.66 & 0.0000 \\
Real rental growth 4 & -20.39 & 2.30 & -8.86 & 0.0000 \\
Real dividend deviation 4 & -1.75 & 0.81 & -2.16 & 0.033 \\
Real dividend growth 4 & 4.67 & 0.79 & 5.89 & 0.0000 \\
Property weight 4 & -0.170 & 0.025 & -6.82 & 0.0000 \\
\hline R-squared & 0.857 & F-statistic & 89.96 \\
Adjusted R-squared & 0.848 & Prob. (F-statistic) & & 0.0000 \\
S.E. of regression & 0.41 & Durbin-Watson & & 0.34 \\
\hline
\end{tabular}


Table 4: Short run model of the office market

\section{(a) With trend}

Dependent Variable: D(Office cap rate)

Sample: 1978:1 to 2001:4

Included observations: 96

\begin{tabular}{ccccc}
\hline Variable & Coefficient & Std. Error & t-statistic & Prob. \\
\hline Constant & 0.0031 & 0.017 & 0.18 & 0.86 \\
D(Stock cap rate) & 0.105 & 0.043 & 2.44 & 0.017 \\
D(Rental deviation 4) & 1.34 & 0.70 & 1.92 & 0.059 \\
D(Real rental growth 4) & -4.38 & 2.62 & -1.67 & 0.098 \\
D(Real dividend deviation 4) & -2.64 & 1.16 & -2.29 & 0.025 \\
D(Real dividend growth 4) & 0.64 & 0.46 & 1.39 & 0.17 \\
D(Property weight 4) & -0.107 & 0.062 & -1.73 & 0.086 \\
ECM & -0.240 & 0.048 & -5.03 & 0.0000 \\
D(Office cap rate) (-1) & 0.304 & 0.088 & 3.46 & 0.0008 \\
\hline R-squared & 0.498 & F-statistic & 10.78 \\
Adjusted R-squared & 0.452 & Prob. (F-statistic) & 0.0000 \\
S.E. of regression & 0.14 & Prob. (Breusch-Godfrey) & 0.53 \\
\hline
\end{tabular}

\section{(b) Without trend}

Dependent Variable: D(Office cap rate)

Sample: 1978:1 to 2001:4

Included observations: 96

\begin{tabular}{ccccc}
\hline Variable & Coefficient & Std. Error & t-statistic & Prob. \\
\hline Constant & 0.0015 & 0.018 & 0.079 & 0.94 \\
D(Stock cap rate) & 0.109 & 0.047 & 2.33 & 0.022 \\
D(Rental deviation 4) & 1.45 & 0.75 & 1.93 & 0.057 \\
D(Real rental growth 4) & -3.04 & 2.92 & -1.04 & 0.30 \\
D(Real dividend deviation 4) & -2.60 & 1.24 & -2.09 & 0.039 \\
D(Real dividend growth 4) & 0.77 & 0.51 & 1.52 & 0.13 \\
D(Property weight 4) & -0.118 & 0.067 & -1.75 & 0.083 \\
ECM & -0.147 & 0.046 & -3.19 & 0.0020 \\
D(Office cap rate) (-1) & 0.329 & 0.096 & 3.41 & 0.0010 \\
\hline R-squared & 0.419 & F-statistic & 7.85 \\
Adjusted R-squared & 0.366 & Prob. (F-statistic) & 0.0000 \\
S.E. of regression & 0.16 & Prob. (Breusch-Godfrey) & 0.44 \\
\hline
\end{tabular}


Table 5: Long run model of the retail market

Dependent Variable: Retail cap rate

Sample: 1977:4 to 2001:4

Included observations: 97

\begin{tabular}{ccccc}
\hline \multicolumn{1}{c}{ Variable } & Coefficient & Std. Error & t-statistic & Prob. \\
\hline Constant & 7.67 & 0.92 & 8.31 & 0.0000 \\
Stock cap rate & 0.079 & 0.095 & 0.84 & 0.41 \\
Rental deviation 4 & 5.16 & 0.58 & 8.83 & 0.0000 \\
Real rental growth 4 & -13.57 & 3.52 & -3.85 & 0.0002 \\
Real dividend deviation 4 & -3.22 & 0.96 & -3.35 & 0.0012 \\
Real dividend growth 4 & 0.53 & 0.90 & 0.59 & 0.56 \\
$\quad$ Property weight 4 & -0.197 & 0.035 & -5.66 & 0.0000 \\
$\quad$ Linear trend & -0.0051 & 0.0060 & -0.85 & 0.40 \\
\hline R-squared & 0.863 & F-statistic & & 80.17 \\
Adjusted R-squared & 0.852 & Prob. (F-statistic) & & 0.0000 \\
S.E. of regression & 0.38 & Durbin-Watson \\
\hline
\end{tabular}


Table 6: Short run model of the retail market

\section{(a) Full model}

Dependent Variable: D(Retail cap rate)

Sample: 1978:1 to 2001:4

Included observations: 96

\begin{tabular}{ccccc}
\hline Variable & Coefficient & Std. Error & t-statistic & Prob. \\
\hline Constant & 0.0076 & 0.0139 & 0.55 & 0.58 \\
D(Stock cap rate) & 0.083 & 0.036 & 2.34 & 0.02 \\
D(Rental deviation 4) & 1.44 & 0.96 & 1.50 & 0.14 \\
D(Real rental growth 4) & -2.23 & 2.60 & -0.86 & 0.39 \\
D(Real dividend deviation4) & -1.29 & 1.08 & -1.19 & 0.24 \\
D(Real dividend growth 4) & 0.60 & 0.40 & 1.47 & 0.15 \\
D(Property weight 4) & -0.025 & 0.050 & -0.50 & 0.62 \\
ECM & -0.153 & 0.038 & -4.07 & 0.0001 \\
D(Retail cap rate) (-1) & 0.540 & 0.078 & 6.89 & 0.0000 \\
\hline R-squared & 0.499 & F-statistic & 10.84 \\
Adjusted R-squared & 0.453 & Prob. (F-statistic) & 0.0000 \\
S.E. of regression & 0.12 & Prob. (Breusch-Godfrey) & 0.34 \\
\hline
\end{tabular}

\section{(b) Truncated}

Dependent Variable: D(Retail cap rate)

Sample: 1978:1 to 2001:4

Included observations: 96

\begin{tabular}{lcccc}
\hline \multicolumn{1}{c}{ Variable } & Coefficient & Std. Error & t-statistic & Prob. \\
\hline D(Stock cap rate) & 0.082 & 0.033 & 2.46 & 0.016 \\
ECM & -0.16 & 0.035 & -4.64 & 0.0000 \\
D(Retail cap rate) $(-1)$ & 0.57 & 0.073 & 7.77 & 0.0000 \\
\hline R-squared & 0.47 & F-statistic & 41.72 \\
Adjusted R-squared & 0.46 & Prob. (F-statistic) & 0.0000 \\
S.E. of regression & 0.12 & Prob. (Breusch-Godfrey) & 1.00 \\
\hline
\end{tabular}


Table 7: Responses to mean reversion and extrapolation variables

\begin{tabular}{cccccc}
\hline & & \multicolumn{2}{c}{$1978-2001$} & \multicolumn{2}{c}{ mid 1973-2001 } \\
\hline \multirow{3}{*}{ Offices } & \multicolumn{2}{c}{ Trend } & No trend & Trend & No trend \\
& & & & & \\
& Mean reversion & 3.19 & 2.72 & 3.00 & 1.84 \\
& Extrapolation & -16.6 & -20.4 & -15.9 & -27.3 \\
\hline \multirow{3}{*}{ Retail } & & & & & \\
& Mean reversion & 5.16 & 5.06 & 4.41 & 2.00 \\
& Extrapolation & -13.6 & -13.3 & -17.2 & -23.6 \\
\hline
\end{tabular}

Table A1: Tests for co-integration

\begin{tabular}{|c|c|c|}
\hline Equation from Table ${ }^{(2)}$ & $\begin{array}{l}\text { Number of co- } \\
\text { integrating vectors }\end{array}$ & $\begin{array}{l}\text { Order of integration of the } \\
\text { residuals }\end{array}$ \\
\hline \multicolumn{3}{|l|}{ Office model } \\
\hline $\begin{array}{ll}(\text { Table 2a) } & \text { (a) } \\
(\text { Table 2a) } & \text { (b) }\end{array}$ & $\begin{array}{c}2 / 3 \\
3 / 1\end{array}$ & $\mathrm{I}(0)$ \\
\hline \multicolumn{3}{|l|}{ Retail model } \\
\hline $\begin{array}{ll}\text { (Table 4) } & \text { (a) } \\
\text { (Table 4) } & \text { (b) }\end{array}$ & $\begin{array}{l}2 / 0^{(4)} \\
2 / 0^{(4)}\end{array}$ & $\mathrm{I}(0)-\mathrm{ADF} ; \mathrm{I}(0)(5 \%)-\mathrm{PP}$ \\
\hline
\end{tabular}

Notes:

(1) All tests undertaken using I(1) variables and with $\mathrm{I}(0)$ variables as exogenous.

(2) All tests undertaken twice: (a) with the rental level assumed $\mathrm{I}(0)$ and (b) with it assumed I(1).

(3) The number of co-integrating vectors is from the test variant that maximises the information criterion: the first number is the Akaike criterion result; the second number is the Schwartz criterion result.

(4) When rental growth and dividend growth are excluded as exogenous variables; otherwise no result due to near singular matrix. 
Figure 1: Capitalization rates

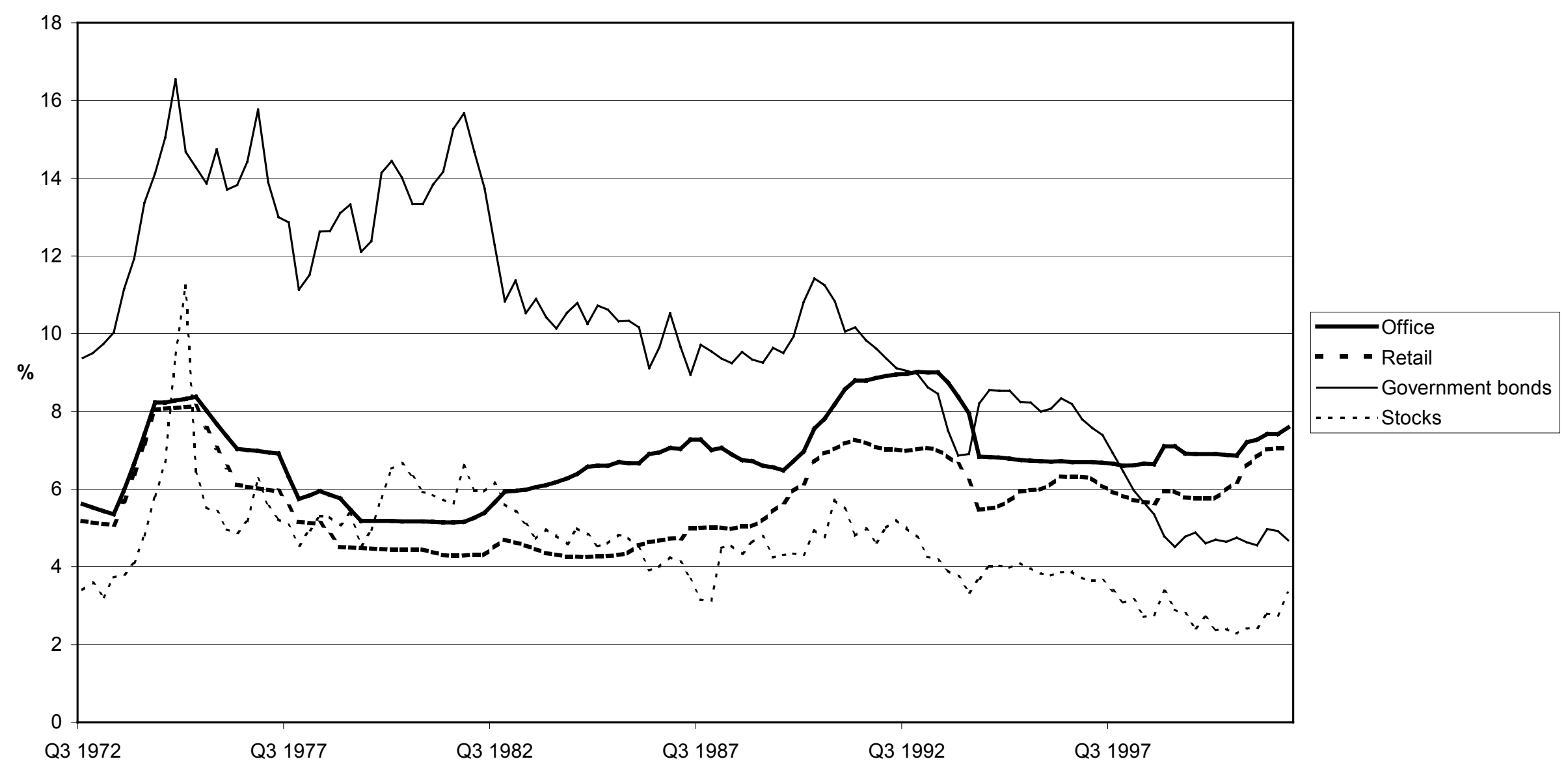


Figure 2: Real rents and dividends

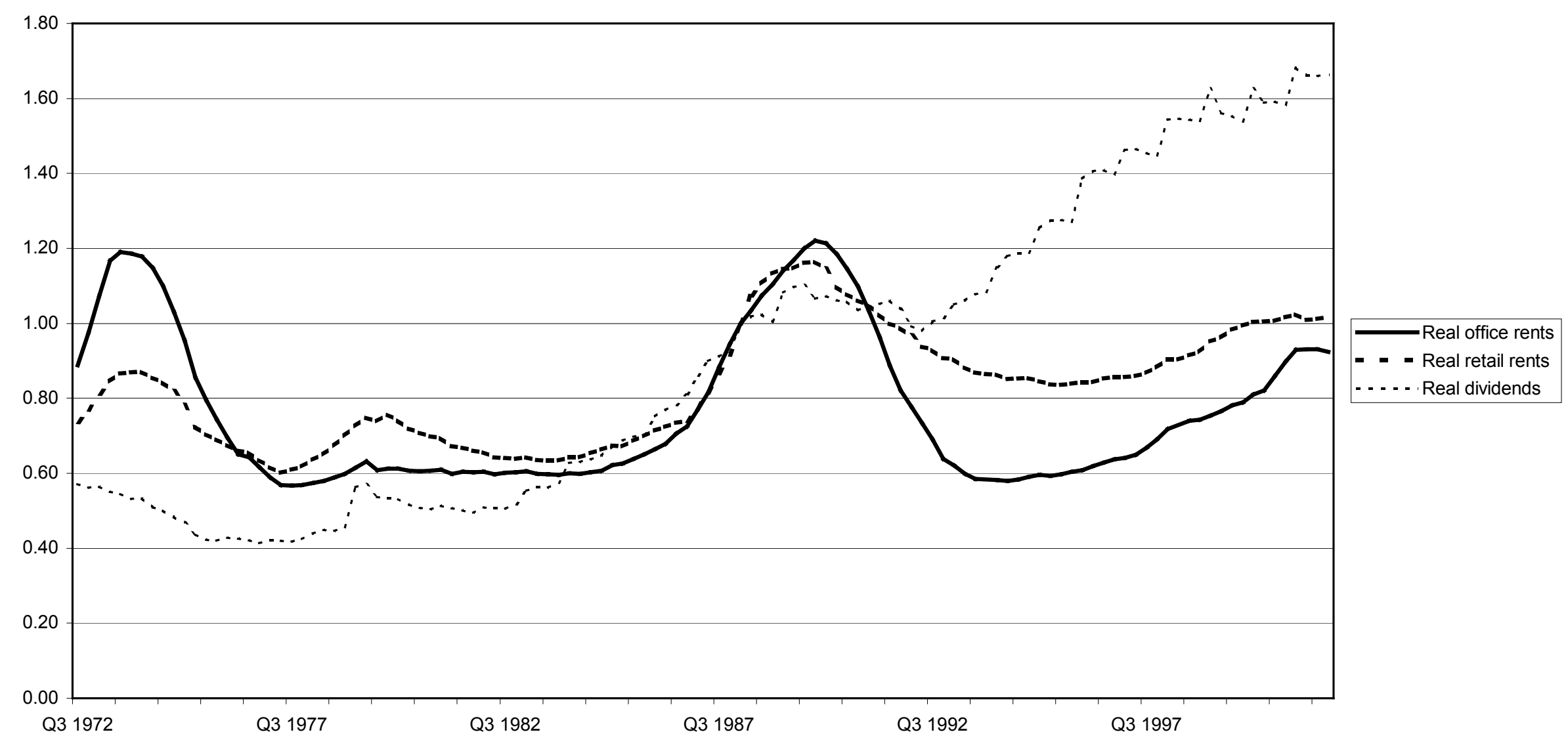


Figure 3: Long run model of the office market

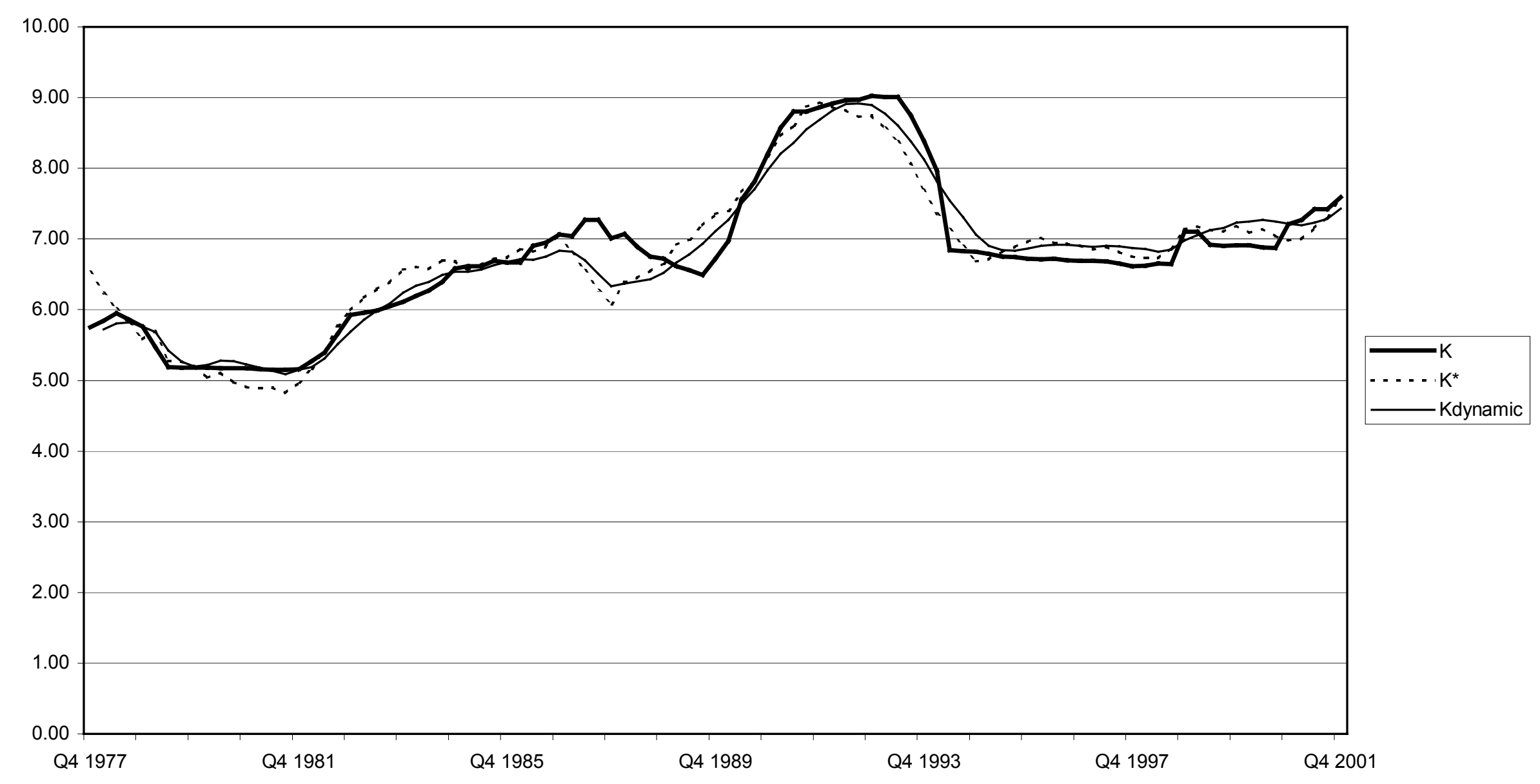


Figure 4: Short run model of the office market

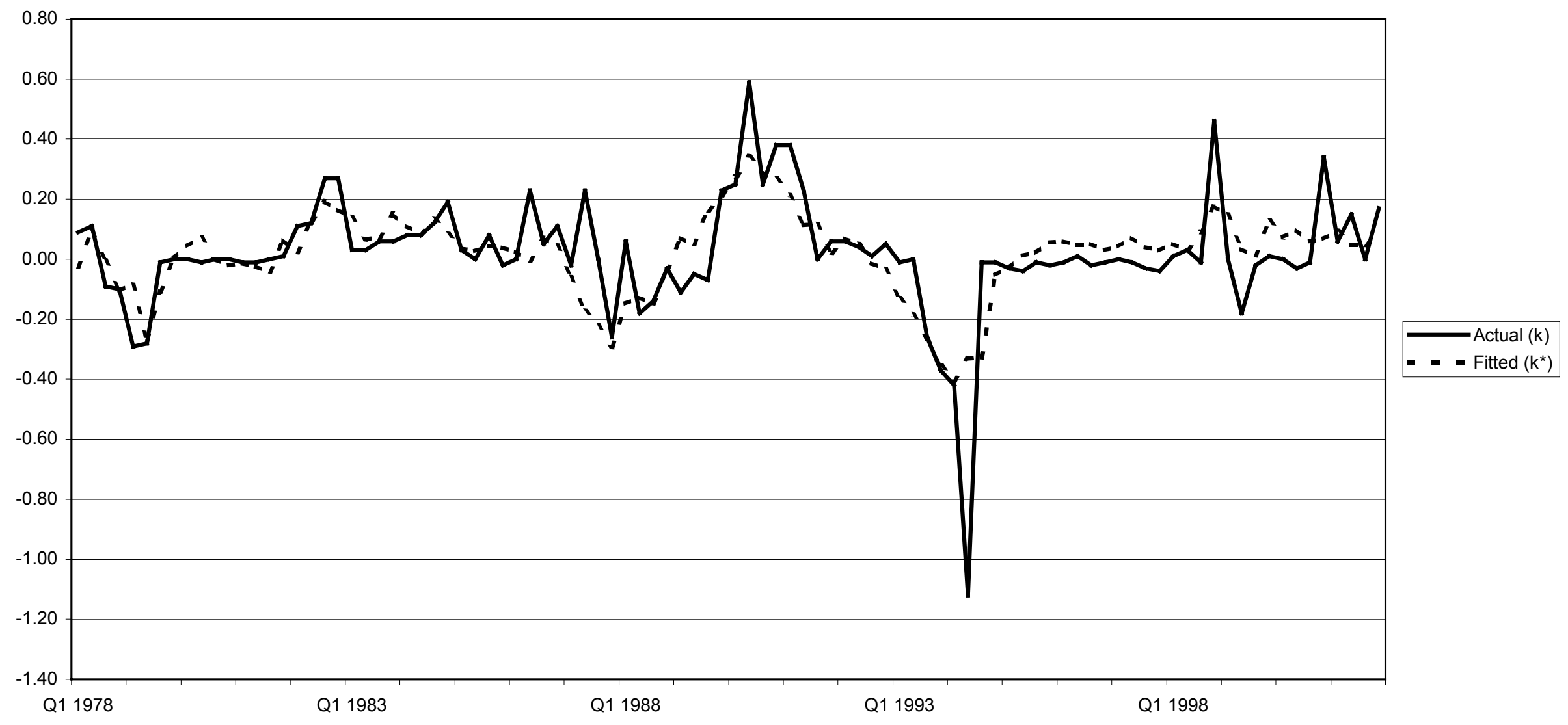


Figure 5: Long run model of the retail market

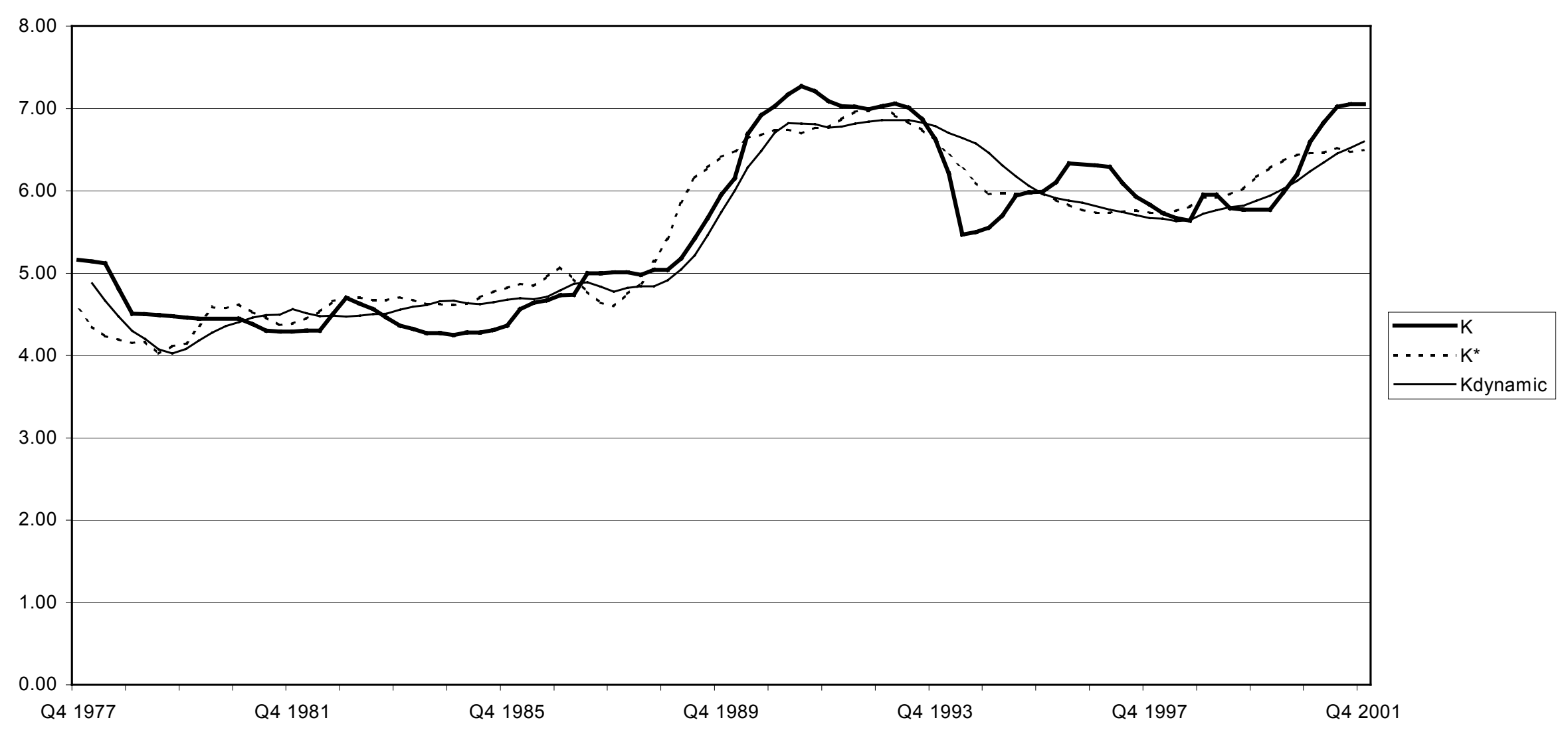


Figure 6: Short run model of the retail market

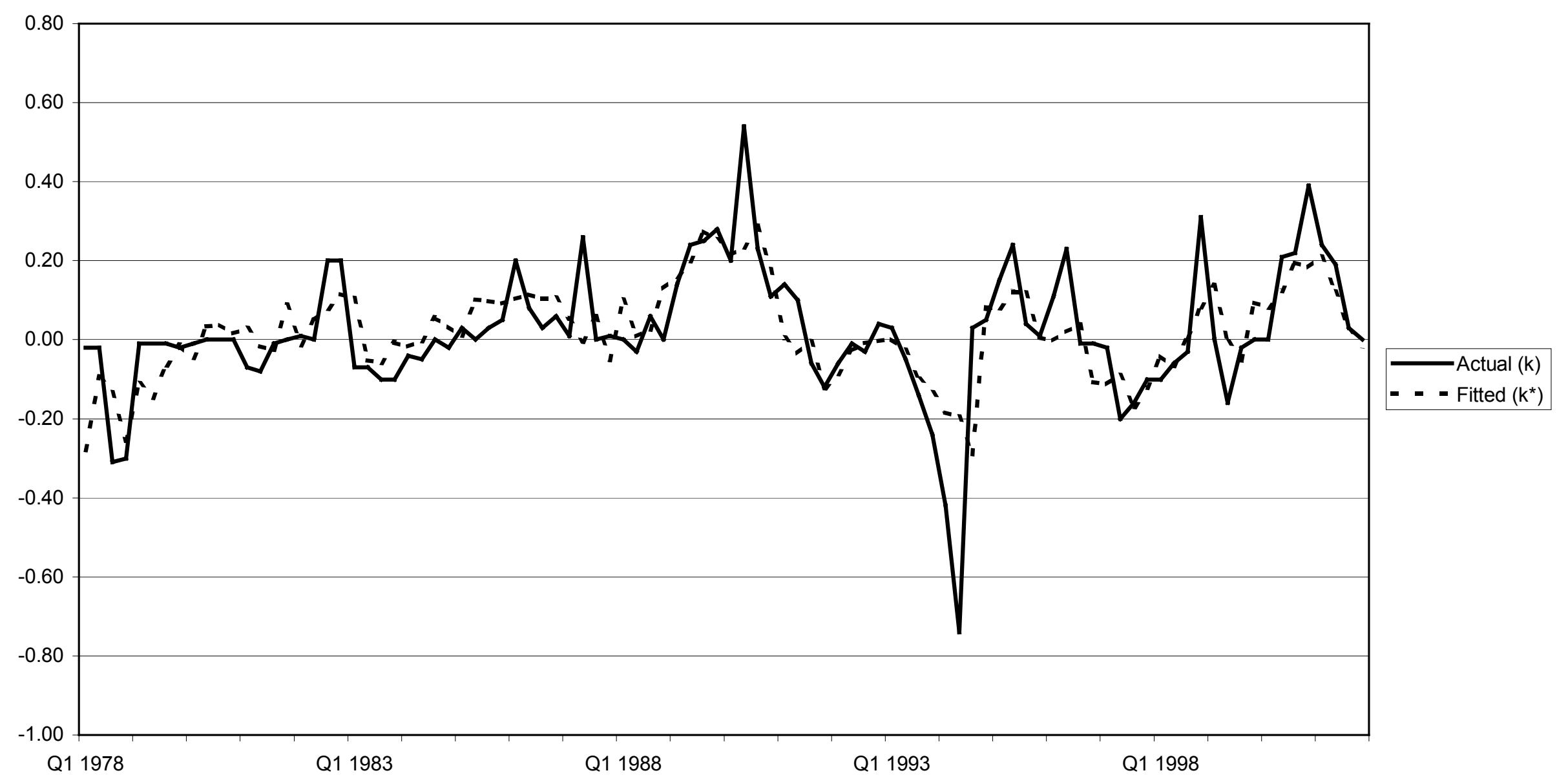


Figure 7: Actual and simulated office market values

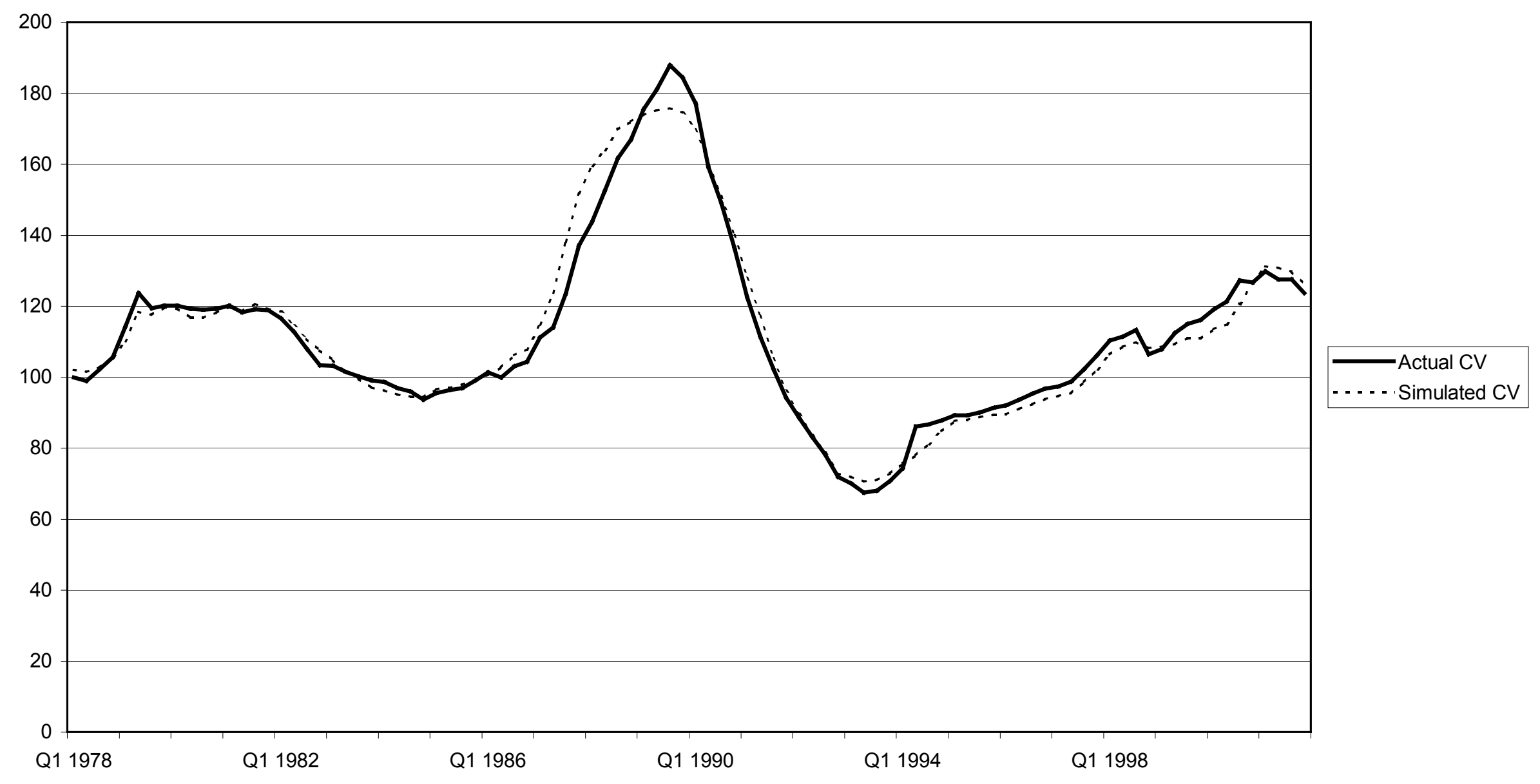


Figure 8: Actual and simulated retail market values

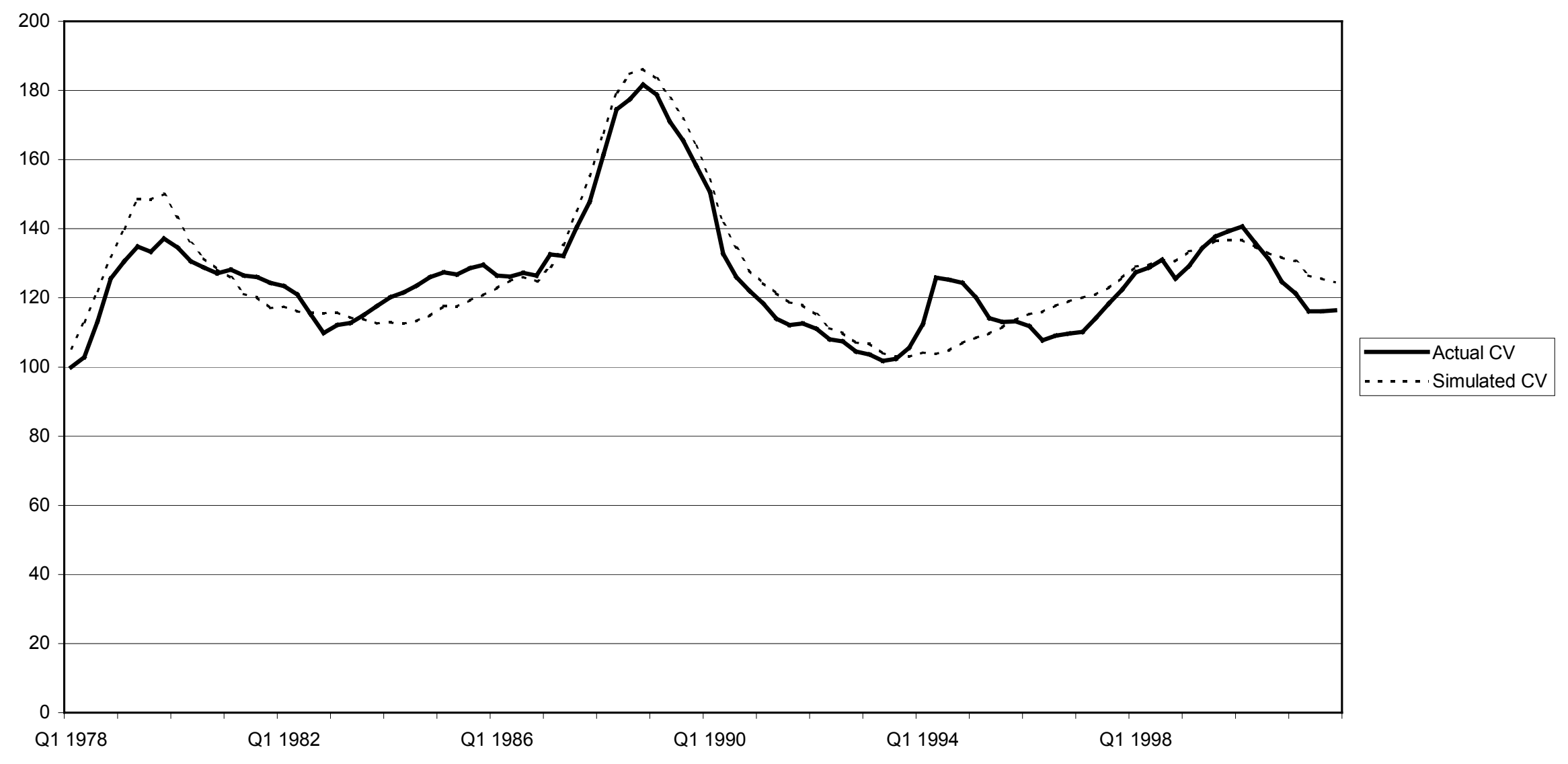

